\title{
Effect of Boron and Sulphur Application on Plant Growth and Yield Attributes of Potato (Solanum tuberosum L.)
}

\author{
Mohammad Ali Muthanna", Anil K. Singh, A. Tiwari, V.K. Jain and M. Padhi
}

Department of Horticulture, Institute of Agricultural Sciences, Banaras Hindu University, Varanasi-221 005, U.P., India

*Corresponding author

\section{A B S T R A C T}

The present investigation was carried out to study the effect of boron and sulphur application on plant morphology and yield of potato during the month of October in 2015-

\section{Keywords}

Sulphur, Boron,

Starch, Total

Soluble Solids.

Article Info

Accepted:

07 September 2017

Available Online:

10 October 2017 16 and 2016-17. The experiment was laid out in randomized block design with three replications and thirteen treatments. Out of thirteen treatments one control, one recommended dose of fertilizers (N/P/K: 150/80/120 kg ha ${ }^{-1}$ ) and eleven treatment combinations along with recommended dose of fertilizers (RDF) including 3 doses of boron (1 kg, $2 \mathrm{~kg}$ and $3 \mathrm{~kg}$ ); 2 doses of sulphur (30 kg and $40 \mathrm{~kg}$ ) and their combinations $(1 \mathrm{~kg}$ boron $+30 \mathrm{~kg}$ sulphur, $2 \mathrm{~kg}$ boron $+30 \mathrm{~kg}$ sulphur, $3 \mathrm{~kg}$ boron $+30 \mathrm{~kg}$ sulphur, $1 \mathrm{~kg}$ boron $+40 \mathrm{~kg}$ sulphur, $2 \mathrm{~kg}$ boron $+40 \mathrm{~kg}$ sulphur and $3 \mathrm{~kg}$ boron $+40 \mathrm{~kg}$ sulphur) were applied. The study indicated that plant morphology and yield of potato plant were significantly influenced by boron and sulphur application. The maximum plant height and yield of marketable tubers (17.99 $\mathrm{t} \mathrm{ha}^{-1}$ and $27.00 \mathrm{t} \mathrm{ha}^{-1}$ ) were recorded in the plants treated with RDF $+2 \mathrm{~kg} \mathrm{~B}+40 \mathrm{~kg} \mathrm{~S}$ during both year of investigation. RDF $+2 \mathrm{~kg} \mathrm{~B}+40 \mathrm{~kg} \mathrm{~S}$ was also found statistically at par with the maximum values under characters viz., number of sprouts per tuber, stem diameter and number of marketable tubers/hill.

\section{Introduction}

Potato (Solanum tuberosum L.) belongs to the family Solanaceae, is a staple food prevailing all across the world with successful largescale production, consumption and affordability with easy availability in the market. It is one of the most diverse and nutritious crops on the planet and can be grown almost all the continents (Khurana and Rana, 2008). It is one of the most remunerative and profitable crop for the farmers due to its higher yield potential within a short span of time (Sati et al., 2017). Potato is a short duration crop, which is highly responsive to high inputs and capable to produce high yield under wide range of soil and climatic conditions. It is second only to maize in terms of number of producer countries and fourth after wheat, maize, rice in global tonnage (Shekhawat, 2001). It is used as vegetable, stock feed and in industries for manufacturing starch, alcoholic beverages and other processed products. The wide flexibility in its planting/sowing and harvesting dates makes the crop most suitable for inclusion in intensive cropping system.

The application of inorganic and organic fertilizers is considered essential to produce 
high tuber yield. To improve productivity, potato plant requires a balanced dose of NPK along with adequate amount of micronutrients and macronutrients like zinc, boron and sulphur. Micronutrients are essential for plant survival and are only needed in small quantities (Kanwar and Youngdhal, 1985). Boron and sulphur are the forgotten element in the recent past is now fast receiving attention because of its widespread deficiency in potato growing areas as well as IndoGangatic plains of India. In potato, sulphur is required for many metabolic activities for plant growth and development and boron play vital role in sprouting, plant growth and tuber enlargement.

The availability of boron in soil is affected considerably by soil $\mathrm{pH}$. At low $\mathrm{pH}$, most of the boron compounds are soluble but in case of sandy soils having low $\mathrm{pH}, \mathrm{B}$ is lost down the profile by leaching if rainfall is high. It occurs mostly in the organic matter in the surface soil and down the profile B content decreases.

Under drought condition the deficiency of boron is observed due to lower availability of B in sub-soils (Prasad, 2014). Its deficiency causes the formation of a bushy plant with droopy leaves. Keeping this in view, present investigation was conducted to see the effect of boron and sulphur application on plant morphology and yield attributes of potato.

\section{Materials and Methods}

The experiment was conducted during the winter of 2015-16 and 2016-17 at Horticulture Research Farm, Department of Horticulture, Institute of Agricultural Sciences, Banaras Hindu University, Varanasi (U.P.), India. The experiment was laid out in Randomized Block Design with thirteen treatments and three replications. Potato cultivar Kufri Lalima was taken as test crop.
The treatments consisted of control, recommended dose of fertilizers $(\mathrm{N} / \mathrm{P} / \mathrm{K}$ : 150/80/120 kg ha $\left.{ }^{-1}\right), \mathrm{RDF}+1 \mathrm{~kg} \mathrm{~B}, \mathrm{RDF}+2$ $\mathrm{kg} \mathrm{B}, \mathrm{RDF}+30 \mathrm{~kg} \mathrm{~S}, \mathrm{RDF}+40 \mathrm{~kg} \mathrm{~S}, \mathrm{RDF}+$ $40 \mathrm{~kg} \mathrm{~S}, \mathrm{RDF}+1 \mathrm{~kg} \mathrm{~B}+30 \mathrm{~kg} \mathrm{~S}, \mathrm{RDF}+2$ $\mathrm{kg} \mathrm{B}+30 \mathrm{~kg} \mathrm{~S}, \mathrm{RDF}+3 \mathrm{~kg} \mathrm{~B}+30 \mathrm{~kg} \mathrm{~S}$, $\mathrm{RDF}+1 \mathrm{~kg} \mathrm{~B}+40 \mathrm{~kg} \mathrm{~S}, \mathrm{RDF}+2 \mathrm{~kg} \mathrm{~B}+40$ $\mathrm{kg} \mathrm{S}$ and $\mathrm{RDF}+3 \mathrm{~kg} \mathrm{~B}+40 \mathrm{~kg} \mathrm{~S}$. The tubers were planted at spacing of $20 \mathrm{~cm} \times 60 \mathrm{~cm}$ in plot size of $3.0 \mathrm{~m} \times 1.2 \mathrm{~m}$ per treatment. Standard cultural practices recommended for potato were followed uniformly for all the experimental plots.

Application of nitrogen, phosphorus and potassium were applied in the form of urea, single super phosphate and murate of potash, respectively. According to treatment details, the basal dressing of phosphorus, potassium, sulphur and boron was done at bottom of the ridge. Half of the total nitrogen per treatment was applied at the time of planting, whereas remaining half was applied after 40 days of planting.

Number of sprouts per tuber was calculated at 40 and 60 days after planting. The diameter of selected stem at random was also measured at 40 and 60 days after planting. The heights of main shoot were measured from the upper portion of ridge to the apex of fully opened leaf. Number of tubers per hill was calculated by formula total number of tubers per replication divided by total numbers of plants per replication. Number of marketable tubers $(\geq 25 \mathrm{~g}$ weight and $\geq 2.5 \mathrm{~cm}$ diameter) and unmarketable tubers $(<25 \mathrm{~g}$ weight and $<2.5$ $\mathrm{cm}$ diameter) per plant was counted. Total yield of marketable tubers was calculated by following formula:

Total yield of marketable tubers $(t /$ ha $)=\frac{\text { Area (ha) }}{\text { Plant area }} \times$ weight of marketable tuber $/$ hill

Statistical analysis is done at $5 \%$ level of significance by SAS 9.4 for windows developed by SAS institute, U.S.A. 


\section{Results and Discussion}

\section{Growth parameters}

\section{Number of sprouts/ tuber}

Number of sprout per tuber is an important morphological trait which may influence the plant population as well as yield of total tubers. Maximum number of sprouts per tuber (6.67) at 40 days after planting was recorded in treatment $\mathrm{RDF}+2 \mathrm{~kg} \mathrm{~B}$ and $\mathrm{RDF}+1 \mathrm{~kg} \mathrm{~B}$ $+30 \mathrm{~kg} \mathrm{~S}$, respectively during first and second year of study (Table 1). It might be due to production of more photosynthates by the application of sulphur and boron in soil. Reason behind production of more photosynthates is that sulphur and nitrogen enhance the recovery of nutrients from the applied fertilizer to potato crop (Sud, 2006). These findings were supported by Bari et al., (2001) and Kumar et al., (2003).

\section{Stem diameter}

The maximum stem diameter recorded first year $(1.43 \mathrm{~cm})$ and second year (1.63) in treatment RDF + $1 \mathrm{~kg} \mathrm{~B} \mathrm{+} 40 \mathrm{~kg} \mathrm{~S}$ and RDF + $2 \mathrm{~kg} \mathrm{~B}$ respectively. It might be due to increase in nitrogen availability with the application of boron and sulphur resulting from production of more chlorophyll causing increase in stem diameter. Gupta and Sanderson (1993) also observed better stem diameter in the treatment $20 \mathrm{~kg} \mathrm{~B}+15 \mathrm{~kg}$ sulphur and Bose and Tripathi (1996) recorded maximum stem diameter by combined application of boron and sulphur in tomato supports the results.

\section{Plant height}

Plant height is a very important morphological trait which may influence the yield of tubers, as photosynthetic activities are more in a vigorous plant in comparison to normal one. Plant height was significantly increased with the application of sulphur and boron and their combinations during both the year of experimentation. During first and second year after 40 days of planting, the maximum plant height $82.00 \mathrm{~cm}$ and 61.33 $\mathrm{cm}$ was recorded in treatment $\mathrm{RDF}+2 \mathrm{~kg} \mathrm{~B}+$ $40 \mathrm{~kg} \mathrm{~S}$.

In both year of investigation after 60 days of planting maximum plant height was also recorded in the same treatment $(\mathrm{RDF}+2 \mathrm{~kg} \mathrm{~B}$ $+40 \mathrm{~kg} \mathrm{~S}$ ). It might be due to application of boron and sulphur in the soil, increased photosynthetic activity in plants which resulted in vigorous growth of plant (Sud et al., 1996). Similar results were also reported by Beri et al., (2000) and Sharma et al., (1999). Abdulnour et al., (2000) reported that excess boron can adversely affect plant growth.

\section{Yield parameters}

On the basis of present investigation it was observed that application of boron, sulphur and combinations significantly influence the yield parameters in potato (Table 2 ).

\section{Numbers of tubers /hill}

Yield attributes like number and weight of tubers directly correlated with yield of the tubers. $\mathrm{RDF}+1 \mathrm{~kg} \mathrm{~B}$ recorded maximum number of tubers (18.67) per hill during first year whereas, RDF $+30 \mathrm{~kg} S$ recorded maximum numbers of tubers (19.17) during second year.

The application of sulphur and boron in deficit soil increase the availability of boron and sulphurin sub-surface soil and result in more photosynthesis which increase number of tubers per plant. The finding was also supported by Sharma et al., (2011), Gupta and Sanderson (1993) and Beri et al., (2001). 
Table.1 Effect of boron and sulphur application on plant growth characters

\begin{tabular}{|c|c|c|c|c|c|c|c|c|c|c|c|c|}
\hline \multirow[t]{3}{*}{ Treatment } & \multicolumn{4}{|c|}{ Number of sprouts per tuber } & \multicolumn{4}{|c|}{ Stem diameter $(\mathrm{cm})$} & \multicolumn{4}{|c|}{ Plant height $(\mathrm{cm})$} \\
\hline & \multicolumn{2}{|c|}{40 DAP } & \multicolumn{2}{|c|}{$60 \mathrm{DAP}$} & \multicolumn{2}{|c|}{40 DAP } & \multicolumn{2}{|c|}{60 DAP } & \multicolumn{2}{|c|}{40 DAP } & \multicolumn{2}{|c|}{60 DAP } \\
\hline & $1^{\text {st }}$ year & $2^{\text {nd }}$ year & $1^{\text {st }}$ year & $2^{\text {nd }}$ year & $1^{\text {st }}$ year & $2^{\text {nd }}$ year & $1^{\text {st }}$ year & $2^{\text {nd }}$ year & $1^{\text {st }}$ year & $2^{\text {nd }}$ year & $1^{\text {st }}$ year & $2^{\text {nd }}$ year \\
\hline Control & 5.33 & 5.33 & 5.33 & 5.33 & 1.07 & 1.23 & 1.20 & 1.33 & 45.00 & 49.00 & 66.00 & 58.31 \\
\hline RDF (NPK:150,80, $120 \mathrm{~kg} / \mathrm{ha})$ & 5.67 & 5.33 & 5.67 & 5.33 & 1.17 & 1.50 & 1.37 & 1.63 & 62.00 & 55.34 & 85.33 & 70.33 \\
\hline $\mathrm{RDF}+1 \mathrm{~kg} \mathrm{~B}$ & 5.00 & 6.00 & 5.00 & 6.00 & 1.30 & 1.43 & 1.50 & 1.70 & 69.00 & 57.68 & 91.65 & 94.67 \\
\hline $\mathrm{RDF}+2 \mathrm{~kg} \mathrm{~B}$ & 6.67 & 3.67 & 6.67 & 3.67 & 1.17 & 1.63 & 1.40 & 1.90 & 61.33 & 55.00 & 81.33 & 82.00 \\
\hline $\mathrm{RDF}+3 \mathrm{~kg} \mathrm{~B}$ & 5.67 & 5.33 & 5.67 & 5.33 & 1.23 & 1.57 & 1.40 & 1.70 & 71.00 & 58.67 & 83.67 & 72.33 \\
\hline $\mathrm{RDF}+30 \mathrm{~kg} \mathrm{~S}$ & 5.67 & 4.67 & 5.67 & 4.67 & 1.27 & 1.60 & 1.43 & 1.97 & 69.35 & 56.67 & 85.00 & 103.00 \\
\hline $\mathrm{RDF}+40 \mathrm{~kg} \mathrm{~S}$ & 5.33 & 5.33 & 5.33 & 5.33 & 1.23 & 1.40 & 1.43 & 1.63 & 64.00 & 56.00 & 89.67 & 76.33 \\
\hline $\mathrm{RDF}+1 \mathrm{~kg} \mathrm{~B}+30 \mathrm{~kg} \mathrm{~S}$ & 3.67 & 6.67 & 3.67 & 6.67 & 1.23 & 1.43 & 1.40 & 1.60 & 60.67 & 50.00 & 81.33 & 59.33 \\
\hline $\mathrm{RFD}+2 \mathrm{~kg} \mathrm{~B}+30 \mathrm{~kg} \mathrm{~S}$ & 3.33 & 4.33 & 3.33 & 4.33 & 1.23 & 1.43 & 1.43 & 1.47 & 62.67 & 55.33 & 85.00 & 78.00 \\
\hline $\mathrm{RDF}+3 \mathrm{~kg} \mathrm{~B}+30 \mathrm{~kg} \mathrm{~S}$ & 4.33 & 6.00 & 4.33 & 6.00 & 1.27 & 1.50 & 1.47 & 1.60 & 69.33 & 55.67 & 82.67 & 68.00 \\
\hline $\mathrm{RDF}+1 \mathrm{~kg} \mathrm{~B}+40 \mathrm{~kg} \mathrm{~S}$ & 4.67 & 5.67 & 4.67 & 5.67 & 1.43 & 1.50 & 1.57 & 1.70 & 75.31 & 50.00 & 96.67 & 80.68 \\
\hline $\mathrm{RDF}+2 \mathrm{~kg} \mathrm{~B}+40 \mathrm{~kg} \mathrm{~S}$ & 5.67 & 4.67 & 5.67 & 4.67 & 1.33 & 1.47 & 1.43 & 1.53 & 82.00 & 61.33 & 92.67 & 104.68 \\
\hline $\mathrm{RDF}+3 \mathrm{~kg} \mathrm{~B}+40 \mathrm{~kg} \mathrm{~S}$ & 6.00 & 4.67 & 6.00 & 4.67 & 1.37 & 1.50 & 1.53 & 1.57 & 69.00 & 51.00 & 92.65 & 62.31 \\
\hline C.D. $(\mathrm{P}=0.05)$ & 2.00 & 2.33 & 2.00 & 2.33 & 0.20 & 0.27 & 0.16 & 0.27 & 17.00 & 10.51 & 15.33 & 19.65 \\
\hline
\end{tabular}

Table.2 Effect of boron and sulphur application on yield parameters

\begin{tabular}{|c|c|c|c|c|c|c|c|c|}
\hline \multirow[t]{2}{*}{ Treatment } & \multicolumn{2}{|c|}{ No. of tubers/plant } & \multicolumn{2}{|c|}{ No. of marketable tubers/hill } & \multicolumn{2}{|c|}{ No. of unmarketable tubers/hill } & \multicolumn{2}{|c|}{ Yield of marketable tubers (t/ha) } \\
\hline & I year & II year & I year & II year & I year & II year & I year & II year \\
\hline Control & 7.83 & 9.63 & 1.25 & 1.17 & 6.58 & 8.46 & 3.82 & 4.49 \\
\hline RDF(NPK:150,80, $120 \mathrm{~kg} / \mathrm{ha})$ & 16.75 & 14.83 & 2.33 & 3.24 & 14.42 & 11.59 & 10.52 & 14.48 \\
\hline $\mathrm{RDF}+1 \mathrm{~kg} \mathrm{~B}$ & 18.67 & 17.58 & 2.67 & 3.40 & 16.00 & 14.18 & 9.79 & 17.36 \\
\hline $\mathrm{RDF}+2 \mathrm{~kg} \mathrm{~B}$ & 11.00 & 15.25 & 2.66 & 3.54 & 8.33 & 11.71 & 14.44 & 19.58 \\
\hline $\mathrm{RDF}+3 \mathrm{~kg} \mathrm{~B}$ & 14.17 & 16.74 & 2.75 & 3.12 & 11.42 & 13.62 & 17.18 & 16.06 \\
\hline $\mathrm{RDF}+30 \mathrm{~kg} \mathrm{~S}$ & 15.58 & 19.17 & 1.92 & 4.02 & 13.67 & 15.15 & 7.99 & 17.77 \\
\hline $\mathrm{RDF}+40 \mathrm{~kg} \mathrm{~S}$ & 14.75 & 15.25 & 2.17 & 3.18 & 12.58 & 12.07 & 10.66 & 18.65 \\
\hline $\mathrm{RDF}+1 \mathrm{~kg} \mathrm{~B}+30 \mathrm{~kg} \mathrm{~S}$ & 13.17 & 14.92 & 2.58 & 3.44 & 10.58 & 11.48 & 14.76 & 13.63 \\
\hline $\mathrm{RFD}+2 \mathrm{~kg} \mathrm{~B}+30 \mathrm{~kg} \mathrm{~S}$ & 13.58 & 16.25 & 3.75 & 3.83 & 9.83 & 12.42 & 15.59 & 23.58 \\
\hline $\mathrm{RDF}+3 \mathrm{~kg} \mathrm{~B}+30 \mathrm{~kg} \mathrm{~S}$ & 13.92 & 14.92 & 3.17 & 3.96 & 10.75 & 10.96 & 16.67 & 20.54 \\
\hline $\mathrm{RDF}+1 \mathrm{~kg} \mathrm{~B}+40 \mathrm{~kg} \mathrm{~S}$ & 14.67 & 15.08 & 1.92 & 3.73 & 12.75 & 11.35 & 10.43 & 19.01 \\
\hline $\mathrm{RDF}+2 \mathrm{~kg} \mathrm{~B}+40 \mathrm{~kg} \mathrm{~S}$ & 16.58 & 16.83 & 3.08 & 4.24 & 13.50 & 12.59 & 17.99 & 27.00 \\
\hline $\mathrm{RDF}+3 \mathrm{~kg} \mathrm{~B}+40 \mathrm{~kg} \mathrm{~S}$ & 10.92 & 13.33 & 4.08 & 4.13 & 6.84 & 9.20 & 17.78 & 21.62 \\
\hline C.D. $(P=0.05)$ & 1.92 & 2.05 & 0.91 & 1.92 & 2.33 & 3.65 & 7.55 & 8.74 \\
\hline
\end{tabular}


Numbers of marketable tubers and unmarketable tubers/hill

The maximum number of marketable tubers was observed in treatment $\mathrm{RDF}+3 \mathrm{~kg} \mathrm{~B}+40$ $\mathrm{kg} \mathrm{S}$ (4.08) during first year whereas; during second year it was observed in treatment RDF $+2 \mathrm{~kg} \mathrm{~B}+40 \mathrm{~S}$ (4.24). The minimum number of unmarketable tubers was observed in control (6.58 and 8.46) during both year of investigation due to minimum numbers of tubers/hill in same treatment. Increase in the number of marketable tubers might be due to application of boron and sulphur in soil increase the uptake of NPK and Zn which improves the $\mathrm{N}$ : $\mathrm{S}$ and IAA: ABA and cytokinin: $\mathrm{ABA}$ ratio, which induces the formation and growth of stolen mainly due to increase in gibberellin content of plant (Pujina, 2004). These results confirmed by the findings of Taheri et al., (2012) and Singh et al., (1995).

\section{Yield of marketable tubers}

It is evident from the data the maximum marketable tuber yields (17.99 and 27.00 t/ha during $1^{\text {st }}$ and $2^{\text {nd }}$ year) were recorded under the treatment $\mathrm{RDF}+2 \mathrm{~kg} \mathrm{~B}+40 \mathrm{~S}$ during both year of investigation. It might be due to application of boron and sulphur fulfils the requirement of sulphur and boron in subsurface zone of soil which improves uptake of other macro and micronutrients resulting enlarged potato tubers are obtain (Sud et al., 1996). Similar observations also recorded by Sati (2017) and Beri et al., (2001).

\section{References}

Abdulnour, J.E., Donnelly, DJ and Barthakur, NN 2000. The effect of boron on calcium uptake and growth in micropropagated potato plantlets. Potato Research, 43(3): 287-295.
Bari, M.S., Rabani, MM, Rahman, MS, Islam, MJ and Hoque, ATM 2001. Effect of zinc, boron, sulphur and magnesium on the growth and yield of potato. Pakistan Journal of Biological Science, 4(9): 1090-1093.

Bose, U.S., and Tripathi, S.K., 1996. Effect of micro nutrients on growth, yield and quality of tomato cv. Pusa Ruby in M. P. Crop Research, 12(1): 61-64.

Gupta, U.C., and Sanderson, JB 1993. Effect of sulfur, calcium, and boron on tissue nutrient concentration and potato yield. Journal of Plant Nutrition, 16(6): 10131023.

Kanwar, J.S., and Youngdahl, LJ 1985. Micronutrients needs of tropical food crops. Fertilizer Research, 7(1): 43-67.

Khurana, S.C., and Rana, M.K., 2000. Potato: Olericulture in India, $1^{\text {st }}$ edn, Kalyani Publishers, New Delhi.

Kumar, R., Singh, GN and Mishra, RL 2003. Effect of boron, calcium and zinc on gladiolus. Journal of Ornamental Horticulture, 6(2): 104-106.

Prasad, R., Kumar, D, Shivay, YS and Rana, DS 2014. Boron in Indian agriculture - a review. Indian Journal of Agronomy, 59(4): 511-517.

Sati, K., Raghav, M, Sati, UC and Lavlesh 2017. Effect of zinc sulphate application on quality of potato. Research on Crops, 18(1): 98-102.

Sharma, D.K., Kushwah, SS, Nema, PK and Rathore, SS 2011. Effect of sulphur on yield and quality of potato (Solanum tuberosum L.). International Journal of Agricultural Research, 6(2): 143-148.

Sharma, S.K., Singh, H and Kohli, UK 1999. Influence of boron and zinc on seed yield and quality in radish. Seed Research, 27(2):154-158.

Shekhawat, G.S., 2001. Potato production and utilization - issues related to technology, storage, processing and export. Journal of the Indian Potato Association, 28(1): 
viii-ix.

Singh, J.P., and Srivastava, OP 1995. Processing and nutritive qualities of potato tubers as affected by fertilizer nutrients and sulphur application. Journal of the Indian Potato Association, 9(3): 115-119.

Sud, K.C., 1996. Effect of phosphorus and sulphur on potato nutrition in Shimla hills. Journal of the Indian Society of Soil Science, 44(3): 440-444.
Sud, K.C., 2006. Anionic balance of nitrogen, phosphorus and sulphur in potato leaves under rainfed conditions in Shimla hills. Journal of the Indian Potato Association, 33 (1): 68-73.

Taheri, S., and Shamabadi, ZA 2013. Effect of planting date and plant density on potato yield, approach energy efficiency. International Journal of Agriculture and Crop Sciences, 5(7): 747-754.

\section{How to cite this article:}

Mohammad Ali Muthanna, Anil K. Singh, A. Tiwari, V.K. Jain and Padhi, M. 2017. Effect of Boron and Sulphur Application on Plant Growth and Yield Attributes of Potato (Solanum tuberosum L.). Int.J.Curr.Microbiol.App.Sci. 6(10): 399-404.

doi: https://doi.org/10.20546/ijcmas.2017.610.049 